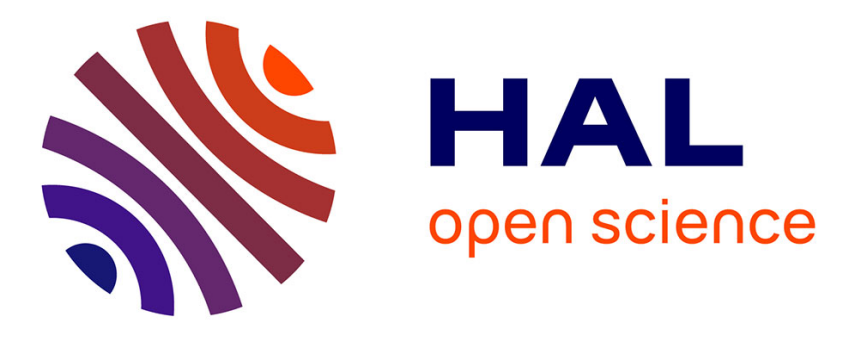

\title{
Aggregating exposures \& cumulating risk for semivolatile organic compounds: A review
}

Maud Pelletier, Nathalie Bonvallot, Philippe Glorennec

\section{To cite this version:}

Maud Pelletier, Nathalie Bonvallot, Philippe Glorennec. Aggregating exposures \& cumulating risk for semivolatile organic compounds: A review. Environmental Research, 2017, 158, pp.649-659. 10.1016/j.envres.2017.06.022 . hal-01635759

\section{HAL Id: hal-01635759 https://hal.science/hal-01635759}

Submitted on 15 Nov 2017

HAL is a multi-disciplinary open access archive for the deposit and dissemination of scientific research documents, whether they are published or not. The documents may come from teaching and research institutions in France or abroad, or from public or private research centers.
L'archive ouverte pluridisciplinaire HAL, est destinée au dépôt et à la diffusion de documents scientifiques de niveau recherche, publiés ou non, émanant des établissements d'enseignement et de recherche français ou étrangers, des laboratoires publics ou privés. 


\section{Aggregating exposures \& cumulating risk for Semivolatile Organic}

\section{Compounds: A review}

3 Maud Pelletier ${ }^{1,2}$, Nathalie Bonvallot ${ }^{1,2}$ Philippe Glorennec ${ }^{1,2^{*}}$

$4 \quad{ }^{1}$ EHESP-School of Public Health, Sorbonne Paris Cité, Rennes, France

52 INSERM-U1085, Irset-Research Institute for Environmental and Occupational Health,

6 Rennes, France

7

$8 \quad$ * Corresponding author:

9 INSERM-U1085, Irset-Research Institute for Environmental and Occupational Health,

10 Rennes, France. EHESP-School of Public Health, Sorbonne Paris Cité, Rennes, France.

11 Tel.: +33 (0) 299022680 .

12 Email: philippe.glorennec@ehesp.fr 


\section{ABSTRACT}

Increasingly, health risk assessment is addressing multiple pathway exposures to multiple contaminants. We reviewed aggregated exposure and cumulative risk approaches for contemporary and ubiquitous semivolatile organic compounds (SVOC). We identified 22 studies aggregating exposure pathways, and 31 cumulating risk. Exposure aggregation is based on the addition of pathway-specific doses, using kinetic modeling where it exists, and classic external dose equations otherwise. In most cases, exposure is dominated by a single route or source of exposure - mainly the oral pathway - via dietary or non-dietary exposure. Preferential routes and sources of exposure are influenced by SVOC physical-chemical properties such as vapor pressure. The cumulative risk approach for contaminants is based on dose addition. Simple sum of hazard quotient (Hazard Index: HI) is the most commonly used cumulative risk assessment approach, while Relative Potency Factor (RPF) appeared to the best suited - although this calls for a level of toxicological information that limits the number of compounds that can be studied simultaneously. Where both were performed, moving from HI to more refined approach produced similar results. In conclusion, both approaches exposure aggregation and cumulative risk - rely on simple assumptions. Nevertheless, they allow uncertainty to be reduced, in comparison with source-by-source or chemical-bychemical approaches.

\section{KEY WORDS}

Mixture; contaminants; environmental exposure; health; exposure pathway; cumulative risk assessment; chemical. 


\section{INTRODUCTION}

People are continuously and increasingly exposed to a multitude of organic chemicals (NHANES 2015) from various sources (e.g. food, dust, cosmetics and personal care products (C\&PCPs), textiles and materials) and media (e.g. air, water and soil), and by different routes of exposure such as inhalation, ingestion or dermal contact. Organic chemicals include a high number of compounds having various physical-chemical properties, and can be classified as volatile, semivolatile or non-volatile compounds. Semivolatile organic compounds (SVOCs) are defined as having a boiling point temperature of between 240 -and $400{ }^{\circ} \mathrm{C}$ (NF ISO 16000-6, 2006). This group includes a high number of organic molecules from different chemical families (e.g. phthalates, bisphenols, polycyclic aromatic hydrocarbons (PAHs), organophosphorus (OPs), organochlorines (OCs), synthetic musks, polychlorinated biphenyls (PCBs), polybromodiphenylethers (PBDEs)). The scientific community's growing interest in studying exposure to SVOCs is motivated by a rise in their use in consumer products as well as by improved analytical techniques that have shown their ubiquity, for example, in dwellings (Rudel et al. 2003; Weschler and Nazaroff 2008). Moreover most are reprotoxic (Peretz et al. 2014; Kay et al. 2014), neurotoxic (Muñoz-Quezada et al. 2013; Costa et al. 2014), or carcinogenic compounds (Armstrong et al. 2004; IARC 2015a, 2015b), and have been found in human biological fluids (blood and urine).

When evaluating the impact of SVOC exposure on human health, exposures may be assessed using either external or internal doses. External dose is estimated from contamination data and human parameters such as body weight, inhalation and dust ingestion rate... Using a pharmacokinetic model or absorption factors, it can be converted to internal dose. Internal dose is preferentially assessed by biomonitoring. Biomonitoring data directly reflect internal aggregate exposures and could, with back calculation using pharmacokinetics models, inform as to the external dose attributable to each exposure pathway. However, using biomonitoring 
data does not inform on the source of exposure that is so useful for prevention strategies. Once exposure is assessed, the risk may be assessed by comparing exposures to a toxicological reference value. This value may be expressed as an external dose for a unique route of exposure, i.e. a reference dose or acceptable daily intake for ingestion (or a reference concentration for inhalation). They are usually estimated from an indicator of the doseresponse relationship in laboratory mammals to which uncertainty factors are applied to take into account inter/intra-species differences (Dybing et al. 2002). For some chemicals, internal reference dose are proposed such as biomonitoring equivalent which are estimates of the concentration of the substance (or a metabolite) in blood or urine that is consistent with the reference dose (Hays and Aylward 2009).

In the case of indoor SVOCs, exposure occurs via different sources and media and concerns many compounds simultaneously. Multiple exposure to mixtures is now widely recognized and addressed, notably by international and national institutions in charge of risk assessment. In the WHO/IPCS Framework for Risk Assessment of Combined Exposures to Multiple Chemicals, aggregate exposure is defined as exposure to the same substance from multiple sources, via multiple pathways, and routes (Meek et al. 2011). Cumulative risk assessment linked to co-exposure to different substances is also recommended when feasible (Meek et al. 2011).

The objective of this study is to review the methods employed in the literature regarding (1) exposure aggregation to an SVOC excluding biomonitoring and (2) cumulative risk assessment for a mixture of SVOCs. 


\section{METHODS}

The search covered the period from 1985 until 2016. Publications were selected in line with the following criteria: addressing SVOC human exposure, aggregating at least two routes of exposure for one SVOC or assessing cumulative risk to at least two SVOCs. Because they do not provide methods for the aggregation of several routes of exposure; publications that considered exposures to an SVOC from different sources (e.g. foodstuff) but via a single exposure route (e.g. ingestion) were discarded, even though aggregation was the mentioned terminology. Using the Web Of Knowledge ${ }^{\mathrm{TM}}$ website (Thomson Reuters, www.webofknowledge.com), publications were selected primarily by searching in the field "topic" (title, abstract and key words): ((exposure AND (assessment OR evaluation) AND (cumulat* OR aggregat*) AND (chemicals OR products OR substances OR compounds OR pollutants) AND health) OR (PBPK AND (SVOC OR pesticide OR phthalate OR flame retardant OR plasticizer OR PCB OR musk OR PAH OR organochlor* OR organophosph* OR pyrethroid) NOT (rat* OR mice OR mouse OR bear). Secondly, selected publications were screened on the basis of the subject-title match. Thirdly, those publications remaining were subjected to an exhaustive abstract reading in order to remove those which did not address the research subject and to separate publications performing exposure aggregation from those dealing with cumulative risk assessment (CRA). Publications identified in the reference list of others were added. Since the objective was to review methods, publications' results are presented only where they allow the comparison of different methods.

Regarding publications that aggregated exposure, the following items were retrieved: references, chemical class, exposure characteristics (source, media, and route of exposure), exposure modeling (type of approach: deterministic or probabilistic, type of aggregated dose, and the doses aggregation level: external or internal), and whether comparison with biomonitoring data was made. Regarding publications that cumulated risks, the following 
106 items were retrieved: references, number of chemical cumulated, SVOC selection criteria 107 (related to occurrence and toxicity), CRA characteristics (grouping by chemical class or not, 108 the dose calculation basis, and the method employed), and toxicity indicators characteristics 109 (type, source, point of departure, and type of toxicological endpoint). 
111 This search identified 22 publications that carried out an exposure aggregation from at least

112 two routes of exposure to an SVOC and 31 publications that carried out a CRA to at least two

113 SVOCs.

114 1. Aggregate exposure assessment

115 Table 1: Publications performing exposure aggregation on semivolatile organic compounds.

117 Twenty-two publications carrying out SVOC exposure aggregation were identified, and these

118 are presented in Table 1. This may seem few, given the high number of compounds 119 concerned, yet assessments are often focused on exposure to a compound from various 120 sources but via a single exposure route. The oldest dates back to 1998 and from 2010 to 2016, 121 one to five publications per year were retrieved from the literature.

122 Seven publications aggregated exposure to OPs, six to phthalates, four to pyrethroids, three to 123 PAHs, three to PBDEs, three to phenols, two to PCBs, two to parabens, one to musks, one to 124 OCs, one to polychlorinated naphthalenes (PCNs), one to perfluoroalkyl acids (PFAAs) and one to replacement flame retardants (RFRs). Residential exposure was studied most (18 publications), addressing exposure to air $(n=16)$, dust $(n=13)$, surfaces $(n=7)$, soil $(n=6)$ and dental sealing $(n=1)$. Fourteen of the publications addressed dietary exposure: all were 128 interested in solid food exposure, four took drinking water into account and three were also 129 interested in breast milk exposure. Three publications addressed occupational source with exposures to air $(n=2)$ or to air and soil $(n=1)$. Two publications addressed exposure to C\&PCPs. 
132 Human exposure to these various sources and media could occur via three pathways: inhalation, ingestion or dermal contact. Of the 22 publications selected, a majority $(n=14)$ aggregated exposure by three pathways, whereas the rest did so by two pathways. As an example, Gosens et al. (2014) aggregated exposure to four parabens contained in C\&PCPs by dermal and ingestion pathways. The reason put forward for not studying exposure by inhalation was that none of the investigated C\&PCPs applied by spray contained parabens. Another reason for not studying a route of exposure is negligible absorption, in comparison with the other pathway. For instance, Wilson et al. (2003) assessed the aggregated exposure by ingestion and inhalation of 37 SVOCs present in several media (indoor and outdoor air, indoor dust, soil and food) rather than by dermal absorption because this was considered negligible in comparison. Because of recent advances in dermal exposure importance (Weschler and Nazaroff 2012) and modeling (Gong et al. 2014; Shi and Zhao 2014; Morrison et al. 2016), this pathway is expected to be more systematically considered in the future. Indeed human experiments with exposure to phthalates have proven this pathway to be significant for some SVOCs (Weschler et al. 2015).

Aggregation of exposure was always conducted by estimating exposure for each route individually, then summing them. These exposures were often assessed by employing classic external dose equations (e.g. U.S. EPA, 1992) combining human parameters (such as weight, body surface area, inhalation rate, amount of ingested dust and frequency of use) with media or product contamination (e.g. SVOC concentration in the media or product). Thirteen publications have used this method. An alternative could be the employment of pharmacokinetic (PK) and/or pharmacodynamics (PD) models to aggregate exposure to individual SVOCs by several routes, and provide an absorbed dose. The physiologicallybased pharmacokinetic model (PBPK), describes the physiological, biochemical, and physical-chemical processes governing the absorption, distribution, metabolism, and excretion 
of a xenobiotic in the body. It consists of a series of compartments receiving the xenobiotic via systemic circulation. These models could also incorporate a pharmacodynamic dimension (PBPK/PD) relating to processes leading to a critical health outcome (e.g. acetylcholinesterase inhibition). PK and PD models require the same parameters as for external dose equations, with the addition of physiological, physiochemical (e.g. partition coefficient) and biochemical (e.g. metabolic rate constant) parameters. Eight publications have used PK models: four used a PBPK model, two a one-compartment PK model and one a PBPK/PD model. The four PBPK models were developed for three different chemical families (PAHs, pyrethroids and OPs), the two one-compartment PK models for PBDE compounds and for PAH compounds, whereas the PBPK/PD model was only developed for OP compounds - chlorpyrifos, to be precise. When PK and/or PD models were available these appeared to be the preferred method for assessment of overall exposure to an SVOC. However, because these are available only for certain specific SVOCs, and because their construction entails high consumption of both data and resources, they are not systematically used. In order to estimate and aggregate exposures to an SVOC, some publications have also used specific exposure models, which include PK modeling components, such as the Stochastic Human Exposure and Dose Simulation model for multimedia (SHEDS-Multimedia) which was developed by the U.S. EPA's Office of Research and Development to simulate aggregate exposure via dietary and residential routes (inhalation and dermal contact) to a variety of environmental chemicals such as pesticides, metals and persistent organic pollutants (https://www.epa.gov/chemicalresearch/stochastic-human-exposure-and-dose-simulation-sheds-estimate-human-exposure).

Three publications used SHEDS-Multimedia to assess exposure to pyrethroid and OP compounds. Another specific model is the Probabilistic Aggregate Consumer Exposure Model (PACEM), first used by Gosens et al. (2014) to facilitate aggregate exposure assessment of parabens compounds present in C\&PCPs. However, though these are more 
adaptable to various SVOCs than are PK and/or PD models, they could be limited by the use of predefined scenarios (e.g. residential pesticide use scenarios using SHEDS-Multimedia, such as indoor flying insect killer, pet treatment, vegetable patch, etc.) or data (e.g. Dutch C\&PCPs use data for PACEM). Compared to classical external dose modeling, most of the time achieved with a deterministic approach, these models use distributions for the human parameters inputs and contamination data in order to allow a probabilistic approach.

Exposure assessment to a contaminant could be expressed as an external or internal dose, the latter reflecting contaminant uptake after crossing absorption barriers. Only Wilson et al. (2003) and Roosens et al. (2010) expressed results as external doses for each route of exposure. Fifteen other publications estimated internal doses for each route of exposure, and five estimated internal dose only for the dermal pathway. Of these, nine publications used a PK approach to convert external exposure into organ, tissue or fluid concentrations. Eleven other publications converted external exposure into internal exposure by applying absorption factors retrieved from the literature or considered a default value of $100 \%$. For the dermal pathway the authors used dermal absorption fraction (Shurdut et al. 1998; Duggan et al. 2003; Linares et al. 2010; Gosens et al. 2014) or a transdermal permeability coefficient (Beko et al. 2013). Transdermal permeability coefficients are more precise, because they take into account partition through the different layers of the skin to the dermal capillaries, and these were recently available in the literature for several SVOCs (Weschler and Nazaroff 2012). This explains why their use has increased since 2013 (in comparison with 1998) for dermal absorption factors. Internal dose appears as the logical metric when considering aggregation of exposure. The most sophisticated approach is PBPK modeling, followed by PK modeling, use of absorption factor, or default $100 \%$ absorption. Using external doses (most often observed for inhalation and ingestion) actually consists in considering that there is no 
differential absorption between exposure routes. This should at least deserve an uncertainty analysis with reported values for bioavailability.

Both external and internal exposure assessments require input parameters (such as human parameters, media or product contamination data and specific parameters of SVOCs). With regard to these parameters, single values could be used to conduct a deterministic approach. A conservative choice of parameters is considered as a lower tier approach by several authors (Delmaar and van Engelen 2006; Sarigiannis et al. 2013), and was indeed employed in ten publications. A higher tier approach could be conducted by probabilistic analyses with Monte Carlo simulation by introducing distributions rather than single values, and this was employed by twelve authors. Both approaches were used and compared by Gosens et al. (2014) to estimate aggregate exposure, by ingestion and dermal contact, to four parabens. Although exposure assessment results were comparable in both approaches, internal exposures estimated by the higher tier approach were always below those estimated by the lower tier approach for each paraben. This result confirmed that a deterministic approach gave a good conservative starting point for exposure assessment but that a probabilistic approach gave a more realistic and more informative exposure assessment where enough data were available (by, for example, allowing estimation of the proportion of population above the reference dose, and enabling sensitivity analysis).

Most of the studies $(n=16)$ aggregated exposures for an average individual using representative data from a population, e.g. a specific age group. Six studies aggregated exposures for specific individuals with their own data.

Most studies $(n=16)$ compared their estimations of aggregate exposure to human biomonitoring data (e.g. NHANES), and eleven of these found consistent results. A reason for 
the discrepancies could be for instance the non-inclusion of a major pathway, such as diet for phthalates (Beko et al. 2013).

It is noteworthy that the authors discussed the contribution made to exposure by each pathway, source or media. The major route of exposure depends on: the studied compounds; the conditions of exposure to these compounds (e.g. residential or occupational), the routes of exposure assessed, and whether the population of interest included children more susceptible to dust ingestion (Beamer et al. 2012; Wason et al. 2012; Gaspar et al. 2014; Mitro et al. 2016). Some authors investigated influent parameters such as SVOC physical-chemical parameters with molecular weight (Beko et al. 2013), and vapor pressure (Wilson et al. 2003), which are related to their partitioning among various media (e.g. indoor air, dust), leading to a preferential route of exposure. As an example, Beko et al. (2013) found the dermal pathway to be the major route of exposure for two phthalates (DnBP and DiBP). Xue et al. (2014) studied exposure to seven pyrethroids when using, or not using, pesticide at home. These authors found ingestion to be the major route of exposure in both cases, with dietary exposure being the most contributive for the population not using pesticides, and non-dietary exposure for the population that does use them. Zartarian et al. (2012) found the same results regarding children's aggregate (dietary and non-dietary) residential exposure to permethrin. The circumstance of exposure also has an influence. For example Wei et al. (2013) studied global exposure to a pyrethroid during and after aircraft disinfection treatments, finding inhalation to be the major route of exposure during the pre-flight spray, and dermal pathway to be the major route of exposure for the residual treatment scenario. The dominant pathway may change depending on exposure level. For example Trudel et al. (2011) found ingestion of food to be the dominant pathway for several PBDEs up to about the $60^{\text {th }}$ quantile of the total dose, while oral and dermal uptake of dust dominated above the $60^{\text {th }}$ quantile, because of a larger variability of concentration and dust ingestion rate. Because few studies $(n=6)$ addressed 
272 Table 2: Publications performing Cumulative Risk Assessment on semivolatile organic 273 compounds.

global exposure to SVOCs via ingestion, inhalation and dermal contact to at least food, air, dust or soil and objects (such as toys, clothing or indoor surfaces), it is difficult to determine a general dominant pathway trend in global exposure assessment to SVOC. However, as observed by Wilson et al. (2003), on the basis of 54 SVOCs, ingestion was found to be the main route of exposure for the less volatile compounds, whereas inhalation was the most significant for the more volatile compounds.

To summarize, choice of method depends strongly on research objectives. A PK and/or PD model seemed preferential when assessing total exposure to an SVOC. However, because they are available only for certain SVOCs, and because their construction involves high data and resource consumption, a lower tier approach - such as employing external dose equation appeared to be more adequate (at least as a first step) and provided consistent estimations. Inclusion of an uncertainty analysis in exposure assessment appears essential in this situation.

Lastly, even where exposure to an SVOC is governed by a major route, aggregating exposure provides useful information regarding exposure characteristics such as influent media, or variation between compounds of the same chemical family.. Aggregation of all routes of exposure to an SVOC appears essential, especially when performing a risk assessment in a second step.

\section{Cumulative Risk Assessment}


Thirty-one publications conducting SVOC CRA were identified for inclusion in this review, and these are presented in Table 2. The oldest dates back to 2003, and since 2009, from one to seven publications per year were retrieved from the literature.

For each study, SVOCs were included in a CRA on the basis of their occurrence and/or a similar pattern of toxicity. Firstly, regarding occurrence, dietary contamination was the most used criterion ( $n=16$ ), followed by the occurrence of SVOC metabolites in humans $(n=8)$. In addition, two studies chose on the basis of their presence in industrial emissions, three on their presence in the residential environment, one on their presence in drinking water, one on their presence in the water, sediment and biota of a specific river and lastly, four studies provided no explanation regarding occurrence for the selection of compounds. Secondly, regarding toxicity patterns for compound selection, having an anti-androgenic mechanism of action $(\mathrm{n}=11)$, or inhibiting the acetylcholinesterase $(\mathrm{AChE})$ mechanism $(\mathrm{n}=11)$ were the most studied effects. In addition, sodium channel modulators, toxic effects on the nervous system, toxic effects on the liver, the reduction of hepatic retinoid, and respiratory irritation were also studied. Finally, five publications based their compound selection on multiple toxic effects. Chemical classes investigated were: carbamates (CBs), OPs, OCs, PAHs, parabens, PBDEs, PCBs, phenols, phthalates, polyfluoroalkylated substances (PFASs) and pyrethroids. In fact, 12 publications studied OP compounds, 11 phthalate compounds, 7 carbamate compounds and 6 pyrethroid compounds. The scientific community's growing interest in OPs and phthalates is driven by suspicion of toxic health effects, such as the anti-androgenic effects of some phthalates on the male reproductive system (Joensen et al. 2012), or the neurotoxic effects of some OPs (Mileson et al.1998), their ubiquitous occurrence in various media (Rudel et al. 2003; Blanchard et al. 2014), and the acknowledged presence of these compounds and their metabolites in human biological fluids (NHANES 2015), as well as - specifically for OPs - the availability of relative potency factors (RPF) published by governmental agencies 
(U.S. EPA 2006). Finally the review reveals that a majority of the publications $(n=26)$ performed CRA for SVOCs coming from the same chemical class and only five encompassed compounds from different families.

A CRA can be performed using several methods that have been developed and used for decades now, notably for regulatory purposes on polluted sites (U.S. EPA 1989). Most of these are based on the following additivity assumptions, notably with the "Incremental Lifetime Cancer Risk", a sum of cancer risks commonly used in regulatory risk assessment. "Dose additivity" assumes that each compound of a mixture is supposed to contribute to the overall observed effect in proportion to its concentration (dose), with the assumption that "toxicants in a mixture act upon similar biological systems and contribute to a common response in proportion to their respective potencies" (Calabrese 1990). On the other hand, "response additivity" assumes that each compound of a mixture is supposed to contribute to the overall observed effect in proportion to its effect (response), with the assumption that "toxicants in a mixture act upon dissimilar biological systems and act independently" (Calabrese 1990). This notion does not take into account the possibility of such toxicological interaction as antagonism or potentiation and could lead to biased estimation of the risk. For example, Boon et al. (2008) have highlighted an overestimation when conducting a CRA to OPs and carbamates exposures. Even though these are known for their common AChE inhibiting activity, their specific mechanisms of action are different - indeed AChE receptor binding is mostly irreversible regarding OPs whereas it is reversible regarding carbamates. However, toxicological interaction (i.e. antagonism or potentiation) is mostly based on the saturation phenomena of metabolic systems, which can be considered as never being achieved regarding low, even sometimes very low (e.g. up to $\mathrm{ng} / \mathrm{m}^{3}$ in indoor air regarding several SVOCs) (Blanchard et al. 2014) compound concentrations in the exposure media (ATSDR 2004). Nevertheless, an empirical analysis of low-dose synergy, by Boobis et al. (2011) 
revealed results of low magnitude (1.5 to 3.5). Furthermore, the principal purpose of risk assessments is to help regulatory or policy-making organizations make decisions and to develop operative strategies regarding the control of human exposure to environmental, residential and occupational pollutants, leading to consideration of the additivity assumptions as operational.

Several CRA methods exist and the most commonly used in the literature are, from the lowest to the highest tier, the Hazard Index (HI) method, the Point of Departure Index (PODI) and the RPF approaches, described extensively elsewhere (U.S. EPA 2000; Sarigiannis and Hansen 2012; Fournier et al. 2014a). Briefly, the HI method is based on the sum of hazard quotients (HQ) for substances affecting the same target organ or system. For each substance involved, the HQ is calculated by dividing exposure by reference dose (i.e. the level at which no adverse effects are expected in humans) (U.S. EPA 2000). This method was used in 20 publications. Although it provides a transparent and comprehensive result $(\mathrm{HI}<1$ indicates that there is little likelihood that an adverse effect might be observed from chronic exposure) this method is also a lower tier approach, because the reference doses are not necessarily constructed with regard to the same target organ, and can sometimes be imprecise with regard to the compounds' mechanism of action. However, it does allow the study of compounds from different chemical classes, but affecting the same target organ or system. Four publications are concerned in this review; all the others studied compounds from a single class $(n=16)$. In order to quantify interaction effects in a mixture, Ragas et al. (2011) followed the interaction-based HI approach developed by the U.S. EPA (2000). This method assumes that interactions among compounds in a complex mixture are dependent on those of all possible binary combinations of the individual mixture components. The $\mathrm{HI}$ is multiplied by a weight factor reflecting the significance of these interactions. The authors observed interaction effects in two groups (with, for instance, four and two pesticides respectively) and 
found that the interaction-based HI was always higher than the conventional one. However, because of weak scientific evidence regarding the calculation procedure, and a weak empirical basis regarding parameter values, the authors have warned that these interaction-based HIs should be used with caution (Ragas et al. 2011).

The PODI approach differs from the HI in that the sum of exposures to each compound is expressed as a fraction of its respective and comparable point of departure (POD) for effects of toxicological relevance (for example, a benchmark dose) rather than a fraction of the reference dose - inducing less uncertainty. The reciprocal of the PODI is the combined margin of exposure (MOE) based on the sum of individual MOEs. For each compound involved, the MOE is calculated by dividing its POD to human exposure (EFSA 2008). Three of the publications used a combined MOE approach.

The RPF approach assumes similarity of mechanisms of action between individual compounds and uses toxicity data for an index compound to normalize the potencies of each other compound in a mixture. Usually the potencies are POD derived from dose-response curves. The combined toxicity of the mixture corresponds to the sum of the potency normalized doses to yield total equivalent exposure, expressed as index compound equivalents, which is then compared to the reference dose of the index compound (EFSA 2008). This method was used in 13 publications. Seven publications studied compounds from the same chemical class - mostly OPs $(n=4)$ - whereas the others studied compounds from different classes $(n=6)$. Four of them applied a RPF approach class by class, whereas Caldas et al. (2006) and Blaznik et al. (2015) performed a RPF approach to OP and CB compounds having the same mechanism of action.

Several publications compared CRA methods. Three publications used both a RPF and a combined MOE approach. One of these is interested in cumulating risks linked to exposure to 
five PCBs, and although the authors found similar results with respect to estimates of median MOE values, they pointed out that the advantage of the RPF approach is that it is more easily implemented in practice, and accounts quantitatively for both variability and the various uncertainties involved (Kalantari et al. 2013). Furthermore, RPF data published by the U.S. EPA are available for the OPs (U.S. EPA 2006), CBs (U.S. EPA 2007), and pyrethroids (U.S. EPA 2011). Benson et al. (2009) and Beamer et al. (2012) found similar results when using both a RPF and an HI approach. Beamer et al. (2012) did not assess the potential added value of a RPF approach to an HI approach, yet Benson et al. (2009) suggested using the less complex HI approach for future CRA to simultaneous phthalates.

The reference doses employed by the authors could differ for a single SVOC according to: the toxicological endpoint studied and the type of POD chosen (no observed adverse effect level (NOAEL), lowest observed adverse effect level (LOAEL) or Benchmark Dose (BMD)); the value of the uncertainty factor applied, and the date of construction, depending on the organization producing these values (e.g. acceptable/tolerable daily intakes (A/TDI) from EFSA or WHO, and reference doses (RfD) from U.S. EPA). Dewalque at al. (2014) and Gao et al. (2016) both calculated HI to several phthalates using two different reference values, (1) TDI from EFSA based on effects on reproduction and development and (2) reference dose from Kortenkamp and Faust (2010) based on anti-androgenic effects. Each author found different results, attesting to the fact that cumulative assessment is dependent on the reference value taken into account.

Dose calculation for exposure estimation was based on contamination data alone in 21 publications and on both contamination and biomonitoring data in 9. Only Beko et al. (2013) estimated daily intakes from both media phthalates compound contaminations (with the exception of foodstuffs) and urinary concentrations of their metabolites before conducting a 
CRA using an HI approach. The authors found an HI from urinary concentrations to be twice 399 as high as from media contaminations.

400 Following a tiered approach when conducting a CRA is now recognized by institutions such 401 as the EFSA's Scientific Panel on Plant Protection products and their Residues (PPR) which 402 recommends the use of tiered approaches when assessing risks of chronic exposure to 403 pesticide residues (EFSA 2008). Several authors of this review have confirmed the pertinence 404 of this recommendation for conducting a CRA on SVOC exposure. A lower tier method (such 405 as the HI approach) could be used as a first step, with recourse to a higher tier method (such 406 as the RPF approach) being justified where the outcome suggests further refinement is called 407 for. 
Aggregate exposures and cumulative risks need to be taken into consideration in addressing total SVOC exposure and the overall risk they pose. In particular, the dermal pathway has proven to be significant in the recent years. This literature review has revealed that relatively simple approaches based on the sum of exposures, doses or effects can be useful, at least in a first tier. However, these first-tier approaches carry their own uncertainties and should be accompanied by an uncertainty analysis of simplifying assumptions. It is however important to keep in mind that not choosing to aggregate exposures or cumulate risks creates more uncertainty because of the implicit assumption of independence of exposures and effects.

This review has highlighted that, because they consider differential absorption rates related to the different routes of exposure, as well as metabolism phenomena, pharmacokinetic models are useful tools for aggregating exposure. Because these are currently available only for certain SVOCs, there is a need for development of generic models for those SVOCs sharing common toxicological effects (e.g. a PBPK model for reprotoxic SVOC). They could also be used for reverse dosimetry using biomonitoring data.

When assessing cumulative risks to several compounds (e.g. in order to build a RPF), a compromise needs to be reached between the exhaustiveness of the compounds list and the required precision of the toxicity estimates for each substance involved in the mixture. A great progress towards putting cumulative risk assessment into practice would be to generate comparable toxicity data in order to build RPF. This may be achieved, for instance, with the use of standardized high-throughput assays as developed last years by the US EPA (Kavlock et al. 2012), associated with the development of omics strategies (i.e. proteomics or transcriptomics). Recent works in these topics are very promising (Hannas et al. 2011; 
431 Thomas et al. 2011, 2012; Van Ravenzwaay et al. 2014; Chauhan et al. 2016; Labib et al. 432 2016).

433 Both PBPK building and toxicity testing is time and resources consuming and a proposal 434 would be to focus efforts on ubiquitous compounds sharing, or suspected to share, the same 435 mechanism of action. A next step would be to identify compounds the populations are 436 frequently exposed to, and then define corresponding cumulative assessment groups, such it 437 has already be done for certain environments (Fournier et al. 2014b), or regulatory processes 438 (Boobis et al. 2008).

440 Acknowledgments: Maud Pelletier's work was funded with a doctoral grant from the 441 Fondation de France and the Agence de l'Environnement et de la maîtrise de l'énergie 442 (Ademe). 
Armstrong, B.; Hutchinson, E.; Unwin, J.; Fletcher, T. Lung cancer risk after exposure to polycyclic aromatic hydrocarbons: A review and meta-analysis. Environ. Health Perspect. 2004, 112 (9), 970-978.

Beamer, P. I.; Canales, R. A.; Ferguson, A. C.; Leckie, J. O.; Bradman, A. Relative pesticide and exposure route contribution to aggregate and cumulative dose in young farmworker children. Int. J. Environ. Res. Public. Health 2012, 9 (1), 73-96.

Beko, G.; Weschler, C. J.; Langer, S.; Callesen, M.; Toftum, J.; Clausen, G. Children's Phthalate Intakes and Resultant Cumulative Exposures Estimated from Urine Compared with Estimates from Dust Ingestion, Inhalation and Dermal Absorption in Their Homes and Daycare Centers. Plos One 2013, 8 (4), e62442.

Benson, R. Hazard to the developing male reproductive system from cumulative exposure to phthalate esters-dibutyl phthalate, diisobutyl phthalate, butylbenzyl phthalate, diethylhexyl phthalate, dipentyl phthalate, and diisononyl phthalate. Regul. Toxicol. Pharmacol. 2009, 53 (2), 90-101.

Blanchard, O.; Glorennec, P.; Mercier, F.; Bonvallot, N.; Chevrier, C.; Ramalho, O.; Mandin, C.; Le Bot, B. Semivolatile Organic Compounds in Indoor Air and Settled Dust in 30 French Dwellings. Environ. Sci. Technol. 2014, 48 (7), 3959-3969.

Blaznik, U.; Yngve, A.; Eržen, I.; Ribič, C. H. Consumption of fruits and vegetables and probabilistic assessment of the cumulative acute exposure to organophosphorus and carbamate pesticides of schoolchildren in Slovenia. Public Health Nutr. 2015, 19 (3), $557-563$. 
Boobis, A. R.; Ossendorp, B. C.; Banasiak, U.; Hamey, P. Y.; Sebestyen, I.; Moretto, A. Cumulative risk assessment of pesticide residues in food. Toxicol. Lett. 2008, 180(2), 137-150.

Boobis, A.; Budinsky, R.; Collie, S.; Crofton, K.; Embry, M.; Felter, S.; Hertzberg, R.; Kopp, D.; Mihlan, G.; Mumtaz, M.; Price, P.; Solomon, K.; Teuschler, L.; Yang, R.; Zaleski, R. Critical analysis of literature on low-dose synergy for use in screening chemical mixtures for risk assessment. Crit. Rev. Toxicol. 2011, 41 (5), 369-383.

Boon, P. E.; Van der Voet, H.; Van Raaij, M. T. M.; Van Klaveren, J. D. Cumulative risk assessment of the exposure to organophosphorus and carbamate insecticides in the Dutch diet. Food Chem. Toxicol. 2008, 46 (9), 3090-3098.

Borg, D.; Lund, B.O.; Lindquist, N.G.; Håkansson, H. Cumulative health risk assessment of 17 perfluoroalkylated and polyfluoroalkylated substances (PFASs) in the Swedish population. Environ. Int. 2013, 59, 112-123.

Bosgra, S.; Voet, H. van der; Boon, P. E.; Slob, W. An integrated probabilistic framework for cumulative risk assessment of common mechanism chemicals in food: An example with organophosphorus pesticides. Regul. Toxicol. Pharmacol. 2009, 54 (2), 124-133.

Calabrese, E. J. Multiple chemical interactions; CRC Press, 1990.

Caldas, E. D.; Boon, P. E.; Tressou, J. Probabilistic assessment of the cumulative acute exposure to organophosphorus and carbamate insecticides in the Brazilian diet. Toxicology 2006, 222 (1-2), 132-142.

Castorina, R.; Bradman, A.; McKone, T. E.; Barr, D. B.; Harnly, M. E.; Eskenazi, B. Cumulative organophosphate pesticide exposure and risk assessment among pregnant 

women living in an agricultural community: a case study from the CHAMACOS cohort. Environ. Health Perspect. 2003, 111 (13), 1640-1648.

Chang, J. W.; Yan, B. R.; Chang, M. H.; Tseng, S. H.; Kao, Y. M.; Chen, J. C.; Lee, C. C. Cumulative risk assessment for plasticizer-contaminated food using the hazard index approach. Environ. Pollut. 2014, 189, 77-84.

Chauhan, V.; Kuo, B.; McNamee, J. P.; Wilkins, R. C.; Yauk, C. L. Transcriptional benchmark dose modeling: Exploring how advances in chemical risk assessment may be applied to the radiation field. Environ. Mol. Mutagen. 2016, 57 (8), 589-604.

Christensen, K. L. Y.; Makris, S. L.; Lorber, M. Generation of hazard indices for cumulative exposure to phthalates for use in cumulative risk assessment. Regul. Toxicol. Pharmacol. 2014, 69 (3), 380-389.

Costa, L. G.; de Laat, R.; Tagliaferri, S.; Pellacani, C. A mechanistic view of polybrominated diphenyl ether (PBDE) developmental neurotoxicity. Toxicol. Lett. 2014, 230 (2), 282-294.

Delmaar, J. E.; van Engelen, J. G. M. Aggregating human exposure to chemicals: An overview of tools and methodologies. The Netherlands: National Institute for Public Health and the Environment (RIVM). Report no. 630700001/2006, 2006.

Dewalque, L.; Charlier, C.; Pirard, C. Estimated daily intake and cumulative risk assessment of phthalate diesters in a Belgian general population. Toxicol. Lett. 2014, 231 (2), $161-168$.

Duggan, A.; Charnley, G.; Chen, W.; Chukwudebe, A.; Hawk, R.; Krieger, R. I.; Ross, J.; Yarborough, C. Di-alkyl phosphate biomonitoring data: assessing cumulative 

$382-395$.

Durmusoglu, E.; Aslan, S.; Can, E.; Bulut, Z. Health Risk Assessment of Workers' Exposure to Organic Compounds in a Tire Factory. Hum. Ecol. Risk Assess. Int. J. 2007, 13 (1), 209-222.

Dybing, E.; Doe, J.; Groten, J.; Kleiner, J.; O'brien, J.; Renwick, A. G.; Schlatter, J.; Steinberg, P.; Tritscher, A.; Walker, R.; Younes, M. Hazard characterisation of chemicals in food and diet: dose response, mechanisms and extrapolation issues. Food Chem. Toxicol. 2002, 40 (2), 237-282.

EFSA Panel on Plant Protection Products and their Residues (PPR) Scientific Opinion on a request from the EFSA evaluate the suitability of existing methodologies and, if appropriate, the identification of new approaches to assess cumulative and synergic risks from pesticides to human health with a view to set MRLs for those pesticides in the frame of Regulation (EC) 396/2005. EFSA J. 2008, 704, 1-85. https://www.efsa.europa.eu/en/efsajournal/pub/705.

Fournier, K.; Glorennec, P.; Bonvallot, N. Construction de valeurs toxicologiques de référence adaptées à la prise en compte des mélanges en évaluation des risques sanitaires: méthodes existantes et applications récentes. Environ. Risques Santé 2014a, $13(3), 203-221$.

Fournier, K.; Glorennec, P.; Bonvallot, N. An exposure-based framework for grouping pollutants for a cumulative risk assessment approach: Case study of indoor semivolatile organic compounds. Environ. Res. 2014b, 130, 20-28. 
Gao, C.-J.; Liu, L.-Y.; Ma, W.-L.; Ren, N.-Q.; Guo, Y.; Zhu, N.-Z.; Jiang, L.; Li, Y.-F.; Kannan, K. Phthalate metabolites in urine of Chinese young adults: Concentration, profile, exposure and cumulative risk assessment. Sci. Total Environ. 2016, 543, 1927.

Gaspar, F. W.; Castorina, R.; Maddalena, R. L.; Nishioka, M. G.; McKone, T. E.; Bradman, A. Phthalate Exposure and Risk Assessment in California Child Care Facilities. Environ. Sci. Technol. 2014, 48 (13), 7593-7601.

Ginsberg, G.; Ginsberg, J.; Foos, B. Approaches to Children's Exposure Assessment: Case Study with Diethylhexylphthalate (DEHP). Int. J. Environ. Res. Public. Health 2016, $13(7), 670$.

Gong, M.; Zhang, Y.; Weschler, C. J. Predicting dermal absorption of gas-phase chemicals: transient model development, evaluation, and application. Indoor Air 2014, 24 (3), 292-306.

Gosens, I.; Delmaar, C. J. E.; ter Burg, W.; de Heer, C.; Schuur, A. G. Aggregate exposure approaches for parabens in personal care products: a case assessment for children between 0 and 3 years old. J Expos Sci Env. Epidemiol 2014, 24 (2), 208-214.

Hannas, B. R.; Lambright, C. S.; Furr, J.; Evans, N.; Foster, P. M.; Gray, L. E.; Wilson, V. S. Genomic biomarkers of phthalate-induced male reproductive developmental toxicity: A targeted rtPCR array approach for defining relative potency. Toxicol. Sci. 2011, $\mathrm{kfr} 315$.

Hays, S. M.; Aylward, L. L. Using biomonitoring equivalents to interpret human biomonitoring data in a public health risk context. J. Appl. Toxicol. 2009, 29 (4), 275288. 
IARC. Polychlorinated biphenyls and polybrominated biphenyls. IARC Monogr. Eval. Carcinog; Risk Chem. Hum. 2015a, 107.

Jardim, A. N. O.; Mello, D. C.; Goes, F. C. S.; Frota Junior, E. F.; Caldas, E. D. Pesticide residues in cashew apple, guava, kaki and peach: GC- $\mu$ ECD, GC-FPD and LCMS/MS multiresidue method validation, analysis and cumulative acute risk assessment. Food Chem. 2014, 164, 195-204.

Jensen, B. H.; Petersen, A.; Nielsen, E.; Christensen, T.; Poulsen, M. E.; Andersen, J. H. Cumulative dietary exposure of the population of Denmark to pesticides. Food Chem. Toxicol. 2015, 83, 300-307.

Joensen, U. N.; Frederiksen, H.; Jensen, M. B.; Lauritsen, M. P.; Olesen, I. A.; Lassen, T. H.; Andersson, A.-M.; Jørgensen, N. Phthalate excretion pattern and testicular function: a study of 881 healthy Danish men. Environ. Health Perspect. 2012, 120 (10), 1397.

Kalantari, F.; Bergkvist, C.; Berglund, M.; Fattore, E.; Glynn, A.; Håkansson, H.; Sand, S. Establishment of the cumulative margin of exposure for a group of polychlorinated biphenyl (PCB) congeners using an improved approach that accounts for both variability and uncertainty. Regul. Toxicol. Pharmacol. 2013, 65 (3), 325-333.

Kavlock, R.; Chandler, K.; Houck, K.; Hunter, S.; Judson, R.; Kleinstreuer, N.; Knudsent, T.; Richard, A.; Martin, M.; Padilla, S.; Reif, D.; Richard, A.; Rotroff, D.; Sipes, N.; Dix, D. Update on EPA's ToxCast program: providing high throughput decision support tools for chemical risk management. Chem. Res. Toxicol. 2012, 25 (7), 1287-1302.

Kay, V. R.; Bloom, M. S.; Foster, W. G. Reproductive and developmental effects of phthalate diesters in males. Crit. Rev. Toxicol. 2014, 44 (6), 467-498. 
Koch, H. M.; Wittassek, M.; Brüning, T.; Angerer, J.; Heudorf, U. Exposure to phthalates in 5-6 years old primary school starters in Germany-A human biomonitoring study and a cumulative risk assessment. Int. J. Hyg. Environ. Health 2011, 214 (3), 188-195.

Kortenkamp, A.; Faust, M. Combined exposures to anti-androgenic chemicals: steps towards cumulative risk assessment. Int. J. Androl. 2010, 33 (2), 463-474.

Kranich, S. K.; Frederiksen, H.; Andersson, A.-M.; Jørgensen, N. Estimated Daily Intake and Hazard Quotients and Indices of Phthtalate Diesters for Young Danish Men. Environ. Sci. Technol. 2014, 48 (1), 706-712.

Labib, S.; Williams, A.; Kuo, B.; Yauk, C. L.; White, P. A.; Halappanavar, S. A framework for the use of single-chemical transcriptomics data in predicting the hazards associated with complex mixtures of polycyclic aromatic hydrocarbons. Arch. Toxicol. 2016, 118.

Leeman, W. R.; Krul, L.; Houben, G. F. Complex mixtures: Relevance of combined exposure to substances at low dose levels. Food Chem. Toxicol. 2013, 58, 141-148.

Li, Z.; Nie, J.; Lu, Z.; Xie, H.; Kang, L.; Chen, Q.; Li, A.; Zhao, X.; Xu, G.; Yan, Z. Cumulative risk assessment of the exposure to pyrethroids through fruits consumption in China - Based on a 3-year investigation. Food Chem. Toxicol. 2016, 96, 234-243.

Linares, V.; Perelló, G.; Nadal, M.; Gómez-Catalán, J.; Llobet, J. M.; Domingo, J. L. Environmental versus dietary exposure to POPs and metals: A probabilistic assessment of human health risks. J Env. Monit 2010, 12 (3), 681-688.

Lorber, M. Exposure of Americans to polybrominated diphenyl ethers. J. Expo. Sci. Environ. Epidemiol. 2007, 18 (1), 2-19. 
Lozowicka, B.; Mojsak, P.; Jankowska, M.; Kaczynski, P.; Hrynko, I.; Rutkowska, E.; Szabunko, J.; Borusiewicz, A. Toxicological studies for adults and children of insecticide residues with common mode of action (MoA) in pome, stone, berries and other small fruit. Sci. Total Environ. 2016, 566-567, 144-156.

Lu, C.; Holbrook, C. M.; Andres, L. M. The implications of using a physiologically based pharmacokinetic (PBPK) model for pesticide risk assessment. Environ. Health Perspect. 2010, 125-130.

Meek, M. E.; Boobis, A. R.; Crofton, K. M.; Heinemeyer, G.; Van Raaij, M.; Vickers, C. Risk assessment of combined exposure to multiple chemicals: A WHO/IPCS framework. Regul Toxicol Pharmacol 2011, 60 (2 suppl 1), S1-S14.

Mileson, B. E.; Chambers, J. E.; Chen, W. L.; Dettbarn, W.; Ehrich, M.; Eldefrawi, A. T.; Gaylor, D. W.; Hamernik, K.; Hodgson, E.; Karczmar, A. G.; et al. Common mechanism of toxicity: a case study of organophosphorus pesticides. Toxicol. Sci. 1998, $41(1), 8-20$.

Mitro, S. D.; Dodson, R. E.; Singla, V.; Adamkiewicz, G.; Elmi, A. F.; Tilly, M. K.; Zota, A. R. Consumer Product Chemicals in Indoor Dust: A Quantitative Meta-analysis of U.S. Studies. Environ. Sci. Technol. 2016, 50 (19), 10661-10672.

Morrison, G. C., Weschler, C. J. and Bekö, G. Dermal uptake directly from air under transient conditions: advances in modeling and comparisons with experimental results for human subjects. Indoor Air, 2016, 26: 913-924.

Muñoz-Quezada, M. T.; Lucero, B. A.; Barr, D. B.; Steenland, K.; Levy, K.; Ryan, P. B.; Iglesias, V.; Alvarado, S.; Concha, C.; Rojas, E.; Vega, C. Neurodevelopmental 
effects in children associated with exposure to organophosphate pesticides: a systematic review. Neurotoxicology 2013, 39, 158-168.

NHANES. Fourth National Report on Human Exposure to Environmental Chemicals. US Department of Health and Human and Service. 2015.

Ogbeide, O.; Tongo, I.; Enuneku, A.; Ogbomida, E.; Ezemonye, L. Human Health Risk Associated with Dietary and Non-Dietary Intake of Organochlorine Pesticide Residues from Rice Fields in Edo State Nigeria. Expo. Health 2016, 8 (1), 53-66.

Ortiz, R. H.; Maître, A.; Barbeau, D.; Lafontaine, M.; Bouchard, M. Use of physiologicallybased pharmacokinetic modeling to simulate the profiles of 3-hydroxybenzo (a) pyrene in workers exposed to polycyclic aromatic hydrocarbons. PloS One 2014, 9 (7), e102570.

Peluso, F.; Othax, N.; Castelain, J. G.; Dubny, S. Applying Health Risk Analysis to Assess the Chemical Quality of Water for Recreational Bathing: The Case of Tres Arroyos Creek, Buenos Aires, Argentina. Hum. Ecol. Risk Assess. Int. J. 2014, 20 (1), 45-68.

Peretz, J.; Vrooman, L.; Ricke, W. A.; Hunt, P. A.; Ehrlich, S.; Hauser, R.; Padmanabhan, V.; Taylor, H. S.; Swan, S. H.; VandeVoort, C. A.; et al. Bisphenol a and reproductive health: update of experimental and human evidence, 2007-2013. Environ. Health Perspect. Online 2014, 122 (8), 775.

Poet, T. S.; Timchalk, C.; Hotchkiss, J. A.; Bartels, M. J. Chlorpyrifos PBPK/PD model for multiple routes of exposure. Xenobiotica 2014, 44 (10), 868-881.

Quijano, L.; Yusà, V.; Font, G.; Pardo, O. Chronic cumulative risk assessment of the exposure to organophosphorus, carbamate and pyrethroid and pyrethrin pesticides 

through fruit and vegetables consumption in the region of Valencia (Spain). Food Chem. Toxicol. 2016.

Ragas, A. M. J.; Oldenkamp, R.; Preeker, N. L.; Wernicke, J.; Schlink, U. Cumulative risk assessment of chemical exposures in urban environments. Environ. Int. 2011, 37 (5), $872-881$.

Van Ravenzwaay, B.; Montoya, G. A.; Fabian, E.; Herold, M.; Krennrich, G.; Looser, R.; Mellert, W.; Peter, E.; Strauss, V.; Walk, T.; Kamp, H. The sensitivity of metabolomics versus classical regulatory toxicology from a NOAEL perspective. Toxicol. Lett. 2014, 227 (1), 20-28.

Roosens, L.; Cornelis, C.; D’Hollander, W.; Bervoets, L.; Reynders, H.; Van Campenhout, K.; Van Den Heuvel, R.; Neels, H.; Covaci, A. Exposure of the Flemish population to brominated flame retardants: Model and risk assessment. Environ. Int. 2010, 36 (4), $368-376$.

Rudel, R.A.; Camann, D. E.; Spengler, J.D.; Korn, L.R.; Brody, J.G. Phthalates, Alkylphenols, Pesticides, Polybrominated Diphenyl Ethers, and Other EndocrineDisrupting Compounds in Indoor Air and Dust. Environ. Sci. Technol. 2003, 37 (20), 4543-4553.

Sarigiannis, D. A.; Hansen, U. Considering the cumulative risk of mixtures of chemicals-A challenge for policy makers. Environ. Health 2012, 11 (Suppl 1), S18.

Sarigiannis, D. A.; Karakitsios, S. P.; Gotti, A. A tiered approach for aggregate exposure assessment- the case of bisphenol-A. In 9th Panhellenic Conference in Chemical Engineering, Athens, Greece 2013. 
Shi, S., \& Zhao, B. Modeled exposure assessment via inhalation and dermal pathways to airborne semivolatile organic compounds (SVOCs) in residences. Environmental science \& technology, 2014, 48(10), 5691-5699.

Shurdut, B. A.; Barraj, L.; Francis, M. Aggregate exposures under the Food Quality Protection Act: an approach using chlorpyrifos. Regul. Toxicol. Pharmacol. 1998, 28 (2), 165-177.

Søeborg, T.; Frederiksen, H.; Andersson, A. M. Cumulative risk assessment of phthalate exposure of Danish children and adolescents using the hazard index approach. Int. J. Androl. 2012, 35 (3), 245-252.

Thomas, R. S.; Clewell, H. J.; Allen, B. C.; Wesselkamper, S. C.; Wang, N. C. Y.; Lambert, J. C.; Hess-Wilson, J. K.; Jay Zhao, Q., Andersen, M. E. Application of transcriptional benchmark dose values in quantitative cancer and noncancer risk assessment. Toxicol. Sci. 2010, kfq355.

Thomas, R. S.; Clewell, H. J.; Allen, B. C.; Yang, L.; Healy, E.; Andersen, M. E. Integrating pathway-based transcriptomic data into quantitative chemical risk assessment: a five chemical case study. Mut. Res./Gen. Tox. EN 2012, 746 (2), 135-143.

Trudel, D.; Scheringer, M.; von Goetz, N.; Hungerbühler, K. Total Consumer Exposure to Polybrominated Diphenyl Ethers in North America and Europe. Environ. Sci. Technol. 2011, 45 (6), 2391-2397.

U.S. EPA. Risk Assessment Guidance for Superfund Volume 1 Human Health Evaluation Manual (Part A). US EPA: Washington, DC, 1989. EPA/540/1-89/002.

U.S. EPA. Guidelines for Exposure Assessment. Risk Assessment Forum; US EPA: Washington, DC, 1992. EPA/600/Z-92/001. 
U.S. EPA. Supplementary guidance for conducting health risk assessment of chemical mixtures. US EPA: Washington, DC, 2000. EPA/630/R-00/002.

U.S. EPA. Organophosphorus Cumulative Risk Assessment; US EPA: Washington, DC, 2006. https://www.epa.gov/pesticide-science-and-assessing-pesticide-risks/cumulativeassessment-risk-pesticides.

U.S. EPA. Revised N-methyl Carbamate Cumulative Risk Assessment; US EPA: Washington, DC, 2007.

U.S. EPA. Pyrethrins/pyrethroid Cumulative Risk Assessment; US EPA: Washington, DC, 2011.

Von Goetz, N.; Wormuth, M.; Scheringer, M.; Hungerbühler, K. Bisphenol A: How the Most Relevant Exposure Sources Contribute to Total Consumer Exposure. Risk Anal. 2010, $30(3), 473-487$.

Wason, S. C.; Smith, T. J.; Perry, M. J.; Levy, J. I. Using physiologically-based pharmacokinetic models to incorporate chemical and non-chemical stressors into cumulative risk assessment: A case study of pesticide exposures. Int. J. Environ. Res. Public. Health 2012, 9 (5), 1971-1983.

Wei, B.; Isukapalli, S. S.; Weisel, C. P. Studying permethrin exposure in flight attendants using a physiologically based pharmacokinetic model. J. Expo. Sci. Environ. Epidemiol. 2013, 23 (4), 416-427.

Weschler, C. J.; Nazaroff, W. W. Semivolatile organic compounds in indoor environments. Atmos. Environ. 2008, 42 (40), 9018-9040. 
Weschler, C. J.; Nazaroff, W. W. SVOC exposure indoors: fresh look at dermal pathways. Indoor Air 2012, 22 (5), 356-377.

Weschler, C. J., Bekö, G., Koch, H. M., Salthammer, T., Schripp, T., Toftum, J., Clausen, G. (2015). Transdermal uptake of diethyl phthalate and di (n-butyl) phthalate directly from air: experimental verification. Environ. Health Perspect. 2015, 123 (10), 928.

Wilson, N. K.; Chuang, J. C.; Lyu, C.; Menton, R.; Morgan, M. K. Aggregate exposures of nine preschool children to persistent organic pollutants at day care and at home. $J$. Expo. Anal. Environ. Epidemiol. 2003, 13 (3), 187-202.

Wormuth, M.; Scheringer, M.; Vollenweider, M.; Hungerbühler, K. What Are the Sources of Exposure to Eight Frequently Used Phthalic Acid Esters in Europeans? Risk Anal. 2006, 26 (3), 803-824.

Xue, J.; Zartarian, V.; Tornero-Velez, R.; Tulve, N. S. EPA's SHEDS-multimedia model: Children's cumulative pyrethroid exposure estimates and evaluation against NHANES biomarker data. Environ. Int. 2014, 73, 304-311.

Zartarian, V.; Xue, J.; Glen, G.; Smith, L.; Tulve, N.; Tornero-Velez, R. Quantifying children's aggregate (dietary and residential) exposure and dose to permethrin: application and evaluation of EPA's probabilistic SHEDS-Multimedia model. $J$ Expos Sci Env. Epidemiol 2012, 22 (3), 267-273.

Zentai, A.; Szabó, I. J.; Kerekes, K.; Ambrus, Á. Risk assessment of the cumulative acute exposure of Hungarian population to organophosphorus pesticide residues with regard to consumers of plant based foods. Food Chem. Toxicol. 2016. 
Table 1: Publications including exposure aggregation on semivolatile organic compounds

\begin{tabular}{|c|c|c|c|c|c|c|c|c|c|c|}
\hline \multirow[b]{2}{*}{$\begin{array}{l}\text { References (year of } \\
\text { publication) }\end{array}$} & \multirow[b]{2}{*}{$\begin{array}{c}\text { Chemical class } \\
\text { (nb. of } \\
\text { publications) }\end{array}$} & \multicolumn{3}{|c|}{ Exposure pathways } & \multicolumn{2}{|c|}{ Exposure modeling } & \multicolumn{3}{|c|}{ Aggregation } & \multirow{2}{*}{$\begin{array}{c}\text { Comparison } \\
\text { with } \\
\text { biomonitoring } \\
\text { data }\end{array}$} \\
\hline & & Source & Media & Route & $\begin{array}{c}\text { Source-to- } \\
\text { external dose }\end{array}$ & $\begin{array}{l}\text { External-to- } \\
\text { internal dose }\end{array}$ & Approach & $\begin{array}{c}\text { Type of } \\
\text { aggregated } \\
\text { dose }\end{array}$ & $\begin{array}{l}\text { Aggregation } \\
\text { level }\end{array}$ & \\
\hline $\begin{array}{l}\text { Ginsberg and Foos } \\
\text { (2016) }\end{array}$ & Phthalates (1) & $\begin{array}{c}\text { Dietary } \\
\text { Residential }\end{array}$ & $\begin{array}{c}\text { Food } \\
\text { Breast milk } \\
\text { Drinking water } \\
\text { Indoor air } \\
\text { Indoor dust } \\
\text { Indoor objects } \\
\text { Clothing }\end{array}$ & $\begin{array}{l}\text { Dermal } \\
\text { Ingestion } \\
\text { Inhalation }\end{array}$ & $\begin{array}{l}\text { External dose } \\
\text { equation }\end{array}$ & $\begin{array}{l}\text { Absorption } \\
\text { factors }\end{array}$ & Deterministic & Internal & $\begin{array}{l}\text { Average } \\
\text { individual }\end{array}$ & Yes \\
\hline Mitro et al. (2016) & $\begin{array}{c}\text { Musks (1) } \\
\text { Parabens (3) } \\
\text { PFAAs (11) } \\
\text { Phenols (7) } \\
\text { Phthalates (8) } \\
\text { RFRs (15) } \\
\end{array}$ & Residential & $\begin{array}{l}\text { Indoor air } \\
\text { Indoor dust }\end{array}$ & $\begin{array}{l}\text { Dermal } \\
\text { Ingestion } \\
\text { Inhalation }\end{array}$ & $\begin{array}{l}\text { External dose } \\
\text { equation }\end{array}$ & $\begin{array}{l}\text { Dermal } \\
\text { absorption } \\
\text { factors }\end{array}$ & Deterministic & $\begin{array}{c}\text { External } \\
\text { (ingestion, } \\
\text { inhalation) } \\
\text { Internal } \\
\text { (dermal) }\end{array}$ & $\begin{array}{l}\text { Average } \\
\text { individual }\end{array}$ & No \\
\hline Gosens et al. (2014) & Parabens (4) & Personal care products & Personal care products & $\begin{array}{l}\text { Dermal } \\
\text { Ingestion }\end{array}$ & $\begin{array}{l}\text { External dose } \\
\text { equation and } \\
\text { PACEM }\end{array}$ & $\begin{array}{l}\text { Absorption } \\
\text { factors }\end{array}$ & $\begin{array}{l}\text { Deterministic } \\
\text { Probabilistic }\end{array}$ & Internal & Individual & No \\
\hline Gaspar et al. (2014) & Phthalates (2) & Residential & $\begin{array}{l}\text { Indoor air } \\
\text { Indoor dust }\end{array}$ & $\begin{array}{c}\text { Dermal } \\
\text { Ingestion } \\
\text { Inhalation }\end{array}$ & $\begin{array}{l}\text { External dose } \\
\text { equation }\end{array}$ & $\begin{array}{l}\text { Dermal } \\
\text { absorption } \\
\text { factors }\end{array}$ & Probabilistic & Internal & $\begin{array}{l}\text { Average } \\
\text { individual }\end{array}$ & No \\
\hline Poet et al. (2014) & OPs (1) & Residential & $\begin{array}{c}\text { Indoor air } \\
\text { Indoor surface (carpet } \\
\text { treated) }\end{array}$ & $\begin{array}{c}\text { Dermal } \\
\text { Inhalation }\end{array}$ & \multicolumn{2}{|c|}{ PBPK/PD model } & Deterministic & Internal & Individual & Yes \\
\hline Ortiz et al. (2014) & PAHs (1) & Occupational & Indoor air & $\begin{array}{l}\text { Dermal } \\
\text { Inhalation }\end{array}$ & \multicolumn{2}{|c|}{$\begin{array}{c}\text { PBPK model and } \\
\text { simple one-compartment PK } \\
\text { model }\end{array}$} & Deterministic & Internal & Individual & Yes \\
\hline Xue et al. (2014) & Pyrethroids (7) & $\begin{array}{c}\text { Dietary } \\
\text { Residential }\end{array}$ & $\begin{array}{c}\text { Food } \\
\text { Indoor air }\end{array}$ & $\begin{array}{c}\text { Dermal } \\
\text { Ingestion } \\
\text { Inhalation }\end{array}$ & $\begin{array}{l}\text { SHEDS- } \\
\text { Multimedia }\end{array}$ & PK model & Probabilistic & Internal & $\begin{array}{l}\text { Average } \\
\text { individual }\end{array}$ & Yes \\
\hline Beko et al. (2013) & Phthalates (5) & Residential & $\begin{array}{l}\text { Gas phase } \\
\text { Particle phase } \\
\text { Indoor dust }\end{array}$ & $\begin{array}{l}\text { Dermal } \\
\text { Ingestion } \\
\text { Inhalation }\end{array}$ & $\begin{array}{l}\text { External dose } \\
\text { equation }\end{array}$ & $\begin{array}{l}\text { Dermal } \\
\text { absorption } \\
\text { factor }\end{array}$ & Probabilistic & $\begin{array}{c}\text { External } \\
\text { (ingestion, } \\
\text { inhalation) } \\
\text { Internal } \\
\text { (dermal) }\end{array}$ & $\begin{array}{l}\text { Average } \\
\text { individual }\end{array}$ & Yes \\
\hline Wei et al. (2013) & Pyrethroids (1) & $\begin{array}{l}\text { Occupational (aircraft } \\
\text { disinfection) }\end{array}$ & Indoor air & $\begin{array}{l}\text { Dermal } \\
\text { Ingestion } \\
\text { Inhalation }\end{array}$ & \multicolumn{2}{|c|}{ PBPK model } & Probabilistic & Internal & $\begin{array}{c}\text { Average } \\
\text { individual }\end{array}$ & Yes \\
\hline Wason et al. (2013) & $\begin{array}{c}\text { Pyrethroids (3) } \\
\text { OPs (2) }\end{array}$ & Residential & $\begin{array}{c}\text { Indoor dust } \\
\text { Indoor surfaces } \\
\text { Soil }\end{array}$ & $\begin{array}{l}\text { Dermal } \\
\text { Ingestion }\end{array}$ & \multicolumn{2}{|c|}{$\begin{array}{l}\text { SHEDS- } \\
\text { Multimedia }\end{array}$} & Probabilistic & Internal & $\begin{array}{l}\text { Average } \\
\text { individual }\end{array}$ & No \\
\hline
\end{tabular}




\begin{tabular}{|c|c|c|c|c|c|c|c|c|c|c|}
\hline \multirow{2}{*}{$\begin{array}{l}\text { Beamer et al. (2012) } \\
\text { Zartarian et al. (2012) }\end{array}$} & \multirow{2}{*}{$\begin{array}{c}\text { OPs (2) } \\
\text { Pyrethroids (1) }\end{array}$} & \multirow{2}{*}{$\begin{array}{c}\text { Dietary } \\
\text { Residential } \\
\text { Dietary } \\
\text { Residential }\end{array}$} & \multirow{2}{*}{$\begin{array}{c}\text { Food } \\
\text { Indoor air } \\
\text { Indoor dust } \\
\text { Indoor surfaces and } \\
\text { toy } \\
\text { Food } \\
\text { Indoor air }\end{array}$} & \multirow{2}{*}{$\begin{array}{c}\text { Dermal } \\
\text { Ingestion } \\
\text { Inhalation } \\
\text { Dermal } \\
\text { Ingestion } \\
\text { Inhalation }\end{array}$} & \multicolumn{2}{|c|}{ PBPK model } & \multirow{2}{*}{$\begin{array}{l}\text { Probabilistic } \\
\text { Probabilistic }\end{array}$} & \multirow{2}{*}{$\begin{array}{l}\text { Internal } \\
\text { Internal }\end{array}$} & \multirow{2}{*}{$\begin{array}{c}\text { Individual } \\
\begin{array}{c}\text { Average } \\
\text { individual }\end{array}\end{array}$} & \multirow{2}{*}{$\begin{array}{l}\text { Yes } \\
\text { Yes }\end{array}$} \\
\hline & & & & & $\begin{array}{c}\text { SHEDS- } \\
\text { Multimedia }\end{array}$ & PK model & & & & \\
\hline Trudel et al. (2011) & PBDEs (8) & $\begin{array}{l}\text { Dietary } \\
\text { Residential }\end{array}$ & $\begin{array}{c}\text { Food } \\
\text { Indoor air } \\
\text { Indoor dust } \\
\text { Indoor surfaces } \\
\text { Soil } \\
\end{array}$ & $\begin{array}{l}\text { Dermal } \\
\text { Ingestion } \\
\text { Inhalation }\end{array}$ & $\begin{array}{l}\text { External dose } \\
\text { equation }\end{array}$ & $\begin{array}{l}\text { Absorption } \\
\text { factors }\end{array}$ & Probabilistic & Internal & $\begin{array}{c}\text { Average } \\
\text { individual }\end{array}$ & Yes \\
\hline Roosens et al. (2010) & PBDEs (6) & $\begin{array}{c}\text { Dietary } \\
\text { Residential }\end{array}$ & $\begin{array}{c}\text { Food } \\
\text { Breast milk } \\
\text { Indoor air } \\
\text { Indoor dust } \\
\text { Soil } \\
\end{array}$ & $\begin{array}{l}\text { Ingestion } \\
\text { Inhalation }\end{array}$ & $\begin{array}{l}\text { External dose } \\
\text { equation }\end{array}$ & No & Probabilistic & External & $\begin{array}{l}\text { Average } \\
\text { individual }\end{array}$ & No \\
\hline Von Goetz et al. (2010) & Phenols (1) & $\begin{array}{l}\text { Dietary } \\
\text { Residential }\end{array}$ & $\begin{array}{c}\text { Food } \\
\text { Breast milk } \\
\text { Indoor air } \\
\text { Indoor dust } \\
\text { Dental sealings }\end{array}$ & $\begin{array}{l}\text { Ingestion } \\
\text { Inhalation }\end{array}$ & $\begin{array}{l}\text { External dose } \\
\text { equation }\end{array}$ & $\begin{array}{l}\text { Absorption } \\
\text { factors }\end{array}$ & Deterministic & Internal & $\begin{array}{l}\text { Average } \\
\text { individual }\end{array}$ & Yes \\
\hline Linares et al. (2010) & $\begin{array}{l}\text { PAHs (16) } \\
\text { PCBs (7) } \\
\text { PCNs (5) }\end{array}$ & $\begin{array}{l}\text { Dietary Occupational } \\
\text { (petrochemistry) }\end{array}$ & $\begin{array}{c}\text { Food } \\
\text { Drinking water } \\
\text { Air } \\
\text { Soil } \\
\end{array}$ & $\begin{array}{l}\text { Dermal } \\
\text { Ingestion } \\
\text { Inhalation }\end{array}$ & $\begin{array}{l}\text { External dose } \\
\text { equation }\end{array}$ & $\begin{array}{l}\text { Dermal } \\
\text { absorption } \\
\text { factor }\end{array}$ & Probabilistic & $\begin{array}{c}\text { External } \\
\text { (ingestion, } \\
\text { inhalation) } \\
\text { Internal } \\
\text { (dermal) } \\
\end{array}$ & $\begin{array}{l}\text { Average } \\
\text { individual }\end{array}$ & No \\
\hline Lu et al. (2010) & OPs (1) & $\begin{array}{l}\text { Dietary } \\
\text { Residential }\end{array}$ & $\begin{array}{c}\text { Food } \\
\text { Drinking water } \\
\text { Indoor air } \\
\text { Indoor dust } \\
\text { Toy surfaces } \\
\text { Soil } \\
\end{array}$ & $\begin{array}{l}\text { Ingestion } \\
\text { Inhalation }\end{array}$ & \multicolumn{2}{|c|}{ PBPK model } & Deterministic & Internal & Individual & Yes \\
\hline Lorber (2007) & PBDEs (9) & $\begin{array}{c}\text { Dietary } \\
\text { Residential }\end{array}$ & $\begin{array}{c}\text { Food } \\
\text { Indoor air } \\
\text { Indoor dust } \\
\text { Soil } \\
\end{array}$ & $\begin{array}{l}\text { Dermal } \\
\text { Ingestion } \\
\text { Inhalation }\end{array}$ & \multicolumn{2}{|c|}{$\begin{array}{c}\text { Simple one-compartment PK } \\
\text { model }\end{array}$} & Deterministic & Internal & $\begin{array}{l}\text { Average } \\
\text { individual }\end{array}$ & Yes \\
\hline Wormuth et al. (2006) & Phthalates (8) & $\begin{array}{c}\text { Dietary } \\
\text { Residential } \\
\text { Personal care products }\end{array}$ & $\begin{array}{c}\text { Food } \\
\text { Indoor air } \\
\text { Outdoor air } \\
\text { Indoor dust } \\
\text { Clothing } \\
\text { Personal care products }\end{array}$ & $\begin{array}{l}\text { Dermal } \\
\text { Ingestion } \\
\text { Inhalation }\end{array}$ & $\begin{array}{l}\text { External dose } \\
\text { equation }\end{array}$ & $\begin{array}{l}\text { Absorption } \\
\text { factors }\end{array}$ & Deterministic & Internal & $\begin{array}{l}\text { Average } \\
\text { individual }\end{array}$ & Yes \\
\hline Duggan et al. (2003) & OPs (31) & $\begin{array}{c}\text { Dietary } \\
\text { Residential }\end{array}$ & $\begin{array}{l}\text { Food } \\
\text { Drinking water } \\
\text { Non-dietary }\end{array}$ & $\begin{array}{l}\text { Dermal } \\
\text { Ingestion } \\
\text { Inhalation }\end{array}$ & $\begin{array}{l}\text { External dose } \\
\text { equation }\end{array}$ & $\begin{array}{l}\text { Dermal } \\
\text { absorption } \\
\text { factor }\end{array}$ & Deterministic & $\begin{array}{c}\text { External } \\
\text { (ingestion, } \\
\text { inhalation) } \\
\text { Internal } \\
\text { (dermal) }\end{array}$ & $\begin{array}{l}\text { Average } \\
\text { individual }\end{array}$ & Yes \\
\hline Wilson et al. (2003) & OCs (9) & Dietary & Food & Ingestion & External dose & No & Deterministic & External & Individual & Yes \\
\hline
\end{tabular}




\begin{tabular}{|c|c|c|c|c|c|c|c|}
\hline & $\begin{array}{c}\text { OPs (2) } \\
\text { PAHs (20) } \\
\text { PCBs (18) } \\
\text { Phenols (3) } \\
\text { Phthalates (2) }\end{array}$ & Residential & $\begin{array}{c}\text { Indoor air } \\
\text { Outdoor air } \\
\text { Indoor dust } \\
\text { Soil }\end{array}$ & Inhalation & equation & & \\
\hline Shurdut et al. (1998) & OPs (1) & $\begin{array}{c}\text { Dietary } \\
\text { Residential }\end{array}$ & $\begin{array}{c}\text { Food } \\
\text { Indoor air } \\
\text { Indoor surfaces }\end{array}$ & $\begin{array}{c}\text { Dermal } \\
\text { Ingestion } \\
\text { Inhalation }\end{array}$ & $\begin{array}{c}\text { External dose } \\
\text { equation }\end{array}$ & $\begin{array}{c}\text { Dermal } \\
\text { absorption } \\
\text { factor }\end{array}$ & $\begin{array}{c}\text { External } \\
\text { (ingestion, } \\
\text { inhalation) } \\
\text { Internal } \\
\text { (dermal) }\end{array}$ \\
$\begin{array}{c}\text { Probabilistic } \\
\text { individual }\end{array}$ \\
\hline
\end{tabular}

OCs = Organochlorines; $\mathrm{OPs}=$ Organophosphorus; PACEM = Probabilistic aggregate consumer exposure model; PAHs = Polycyclic aromatic hydrocarbons; PBDEs = Polybrominated diphenyl ethers; PCBs = Polychlorinated biphenyls; PCNs = Polychlorinated naphthalenes; PFAAs = Perfluoroalkyl acids; RFRs = Replacement flame retardants; SHEDS-multimedia $=$ Stochastic human exposure and dose simulation model for multimedia. 
Table 2: Publications performing cumulative risk assessment (CRA) on semivolatile organic compounds

\begin{tabular}{|c|c|c|c|c|c|c|c|c|c|c|}
\hline \multirow{2}{*}{$\begin{array}{l}\text { References (year } \\
\text { of publication) }\end{array}$} & \multirow{2}{*}{$\begin{array}{l}\text { Number of } \\
\text { chemicals } \\
\text { cumulated }\end{array}$} & \multicolumn{2}{|c|}{ SVOCs selection criteria } & \multicolumn{3}{|c|}{ CRA } & \multicolumn{4}{|c|}{ Toxicity indicators } \\
\hline & & Occurrence & Toxicity & $\begin{array}{c}\text { Grouping by } \\
\text { chemical } \\
\text { class }\end{array}$ & $\begin{array}{c}\text { Dose } \\
\text { calculation } \\
\text { basis }\end{array}$ & Method & Type & Source & $\begin{array}{c}\text { Type of toxicological } \\
\text { endpoint }\end{array}$ & POD \\
\hline Li et al. (2016) & Pyrethroids (7) & $\begin{array}{c}\text { Dietary } \\
\text { contamination }\end{array}$ & AChE inhibitors & Yes & $\begin{array}{c}\text { Contamination } \\
\text { data }\end{array}$ & $\mathrm{HI}$ & $\begin{array}{l}\text { ADI } \\
\text { RfD }\end{array}$ & na & na & na \\
\hline $\begin{array}{l}\text { Lozowicka et al. } \\
\text { (2016) }\end{array}$ & $\begin{array}{c}\text { CBs (1) } \\
\text { OPs (3) } \\
\text { Pyrethroids (3) }\end{array}$ & $\begin{array}{c}\text { Dietary } \\
\text { contamination }\end{array}$ & $\begin{array}{c}\text { AChE inhibitors } \\
\text { Sodium channel } \\
\text { modulators }\end{array}$ & Yes & $\begin{array}{c}\text { Contamination } \\
\text { data }\end{array}$ & $\mathrm{HI}$ & ADI & EFSA & na & na \\
\hline $\begin{array}{l}\text { Quijano et al. } \\
\quad(2016)\end{array}$ & $\begin{array}{c}\text { CBs (7) } \\
\text { OPs (12) } \\
\text { Pyrethroids (7) } \\
\end{array}$ & $\begin{array}{c}\text { Dietary } \\
\text { contamination }\end{array}$ & AChE inhibitors & Yes & $\begin{array}{c}\text { Contamination } \\
\text { data }\end{array}$ & RPF & $\begin{array}{l}\text { RPF } \\
\text { ADI }\end{array}$ & U.S. EPA & AChE activity & $\begin{array}{l}\text { NOAEL } \\
\text { BMD }\end{array}$ \\
\hline \multirow[t]{2}{*}{ Zentai et al. (2016) } & \multirow[t]{2}{*}{ OPs (24) } & \multirow{2}{*}{$\begin{array}{c}\text { Dietary } \\
\text { contamination }\end{array}$} & \multirow[t]{2}{*}{ AChE inhibitors } & \multirow[t]{2}{*}{ Yes } & \multirow{2}{*}{$\begin{array}{l}\text { Contamination } \\
\text { data }\end{array}$} & \multirow[t]{2}{*}{ RPF } & RPF & $\begin{array}{c}\text { Boon et al. (2008) } \\
\text { Caldas et al. (2006) }\end{array}$ & \multirow[t]{2}{*}{ AChE activity } & \multirow{2}{*}{$\begin{array}{l}\text { NOAEL } \\
\mathrm{BMD}_{10}\end{array}$} \\
\hline & & & & & & & RfD & JMPR & & \\
\hline \multirow{2}{*}{ Gao et al. (2016) } & \multirow{2}{*}{ Phthalates (3) } & \multirow{2}{*}{$\begin{array}{c}\text { Urinary } \\
\text { measurement }\end{array}$} & \multirow{2}{*}{$\begin{array}{c}\text { Multiple } \\
\text { Anti-androgenic }\end{array}$} & \multirow{2}{*}{ Yes } & \multirow{2}{*}{$\begin{array}{c}\text { Biomonitoring } \\
\text { data }\end{array}$} & \multirow{2}{*}{$\mathrm{HI}$} & TDI & EFSA & $\begin{array}{c}\text { Effects on reproduction } \\
\text { and development }\end{array}$ & \multirow{2}{*}{$\begin{array}{l}\text { NOAEL } \\
\text { LOAEL } \\
\text { BMD }\end{array}$} \\
\hline & & & & & & & RfD & $\begin{array}{c}\text { Kortenkamp and Faust } \\
(2010)\end{array}$ & Anti-Androgenic & \\
\hline $\begin{array}{l}\text { Ogbeide et al. } \\
\text { (2016) }\end{array}$ & OCs (13) & $\begin{array}{l}\text { Water, sediment } \\
\text { and biota } \\
\text { contamination }\end{array}$ & - & Yes & $\begin{array}{l}\text { Contamination } \\
\text { data }\end{array}$ & $\mathrm{HI}$ & RfD & U.S. EPA & na & na \\
\hline Jensen et al. (2015) & $\begin{array}{l}\text { Different classes of } \\
\text { pesticides (20) }\end{array}$ & $\begin{array}{c}\text { Dietary } \\
\text { contamination }\end{array}$ & Multiple & No & $\begin{array}{c}\text { Contamination } \\
\text { data }\end{array}$ & $\mathrm{HI}$ & ADI & $\begin{array}{c}\text { EC } \\
\text { EFSA } \\
\text { JMPR }\end{array}$ & na & na \\
\hline $\begin{array}{l}\text { Blaznik et al. } \\
\quad(2015)\end{array}$ & $\begin{array}{l}\text { CBs (4) } \\
\text { OPs (10) }\end{array}$ & $\begin{array}{c}\text { Dietary } \\
\text { contamination }\end{array}$ & AChE inhibitors & No & $\begin{array}{l}\text { Contamination } \\
\text { data }\end{array}$ & RPF & $\begin{array}{l}\text { RPF } \\
\text { RfD }\end{array}$ & $\begin{array}{l}\text { Boon et al. (2008) } \\
\text { European commission }\end{array}$ & AChE activity & $\begin{array}{l}\text { NOAEL } \\
\text { LOAEL } \\
\text { BMD }_{10}\end{array}$ \\
\hline \multirow{2}{*}{$\begin{array}{l}\text { Kranich et al. } \\
\quad \text { (2014) }\end{array}$} & \multirow{2}{*}{ Phthalates (5) } & \multirow{2}{*}{ - } & \multirow{2}{*}{ Anti-androgenic } & \multirow{2}{*}{ Yes } & \multirow{2}{*}{$\begin{array}{c}\text { Biomonitoring } \\
\text { data }\end{array}$} & \multirow{2}{*}{$\mathrm{HI}$} & TDI & EFSA & $\begin{array}{l}\text { Effects on reproduction } \\
\text { and development }\end{array}$ & \multirow{2}{*}{$\begin{array}{l}\text { NOAEL } \\
\text { LOAEL } \\
\text { BMD }\end{array}$} \\
\hline & & & & & & & RfD & $\begin{array}{c}\text { Kortenkamp and Faust } \\
(2010)\end{array}$ & Anti-Androgenic & \\
\hline Peluso et al. (2014) & OCs (9) & $\begin{array}{c}\text { Water } \\
\text { contamination } \\
\end{array}$ & Multiple & Yes & $\begin{array}{c}\text { Contamination } \\
\text { data }\end{array}$ & $\mathrm{HI}$ & RfD & $\begin{array}{l}\text { U.S. EPA } \\
\text { IRIS }\end{array}$ & na & na \\
\hline \multirow{2}{*}{ Xue et al. (2014) } & \multirow{2}{*}{ Pyrethroids (7) } & \multirow{2}{*}{$\begin{array}{c}\text { Residential } \\
\text { (consumer use) } \\
\text { Urinary } \\
\text { measurement }\end{array}$} & \multirow[b]{2}{*}{-} & Yes & Contamination & RPF & RPF & US. EPA & na & na \\
\hline & & & & Yes & data & RPF & RfD & U.S. EPA & na & na \\
\hline Chang et al. (2014) & Phthalates (7) & - & Anti-androgenic & Yes & Contamination & HI & TDI & $\begin{array}{l}\text { EFSA } \\
\text { WHO }\end{array}$ & Hepatotoxicity & na \\
\hline & & & & & & & RfD & U.S. EPA & Anti-Androgenic & \\
\hline
\end{tabular}




\begin{tabular}{|c|c|c|c|c|c|c|c|c|c|c|}
\hline \multirow{2}{*}{$\begin{array}{l}\text { Dewalque et al. } \\
\text { (2014) }\end{array}$} & \multirow{2}{*}{ Phthalates (4) } & \multirow{2}{*}{$\begin{array}{c}\text { Urinary } \\
\text { measurement }\end{array}$} & \multirow{2}{*}{ Anti-androgenic } & \multirow{2}{*}{ Yes } & \multirow{2}{*}{$\begin{array}{l}\text { Biomonitoring } \\
\text { data }\end{array}$} & \multirow{2}{*}{ HI } & TDI & EFSA & $\begin{array}{c}\text { Effects on reproduction } \\
\text { and development }\end{array}$ & \multirow{2}{*}{$\begin{array}{l}\text { NOAEL } \\
\text { LOAEL } \\
\text { BMD }\end{array}$} \\
\hline & & & & & & & RfD & $\begin{array}{c}\text { Kortenkamp and Faust } \\
(2010)\end{array}$ & Anti-Androgenic & \\
\hline \multirow{2}{*}{$\begin{array}{l}\text { Christensen et al. } \\
\text { (2014) }\end{array}$} & \multirow{2}{*}{ Phthalates (5) } & \multirow{2}{*}{$\begin{array}{c}\text { Dietary } \\
\text { contamination } \\
\text { Urinary } \\
\text { measurement }\end{array}$} & \multirow{2}{*}{ Anti-androgenic } & \multirow{2}{*}{ Yes } & \multirow{2}{*}{$\begin{array}{l}\text { Biomonitoring } \\
\text { data }\end{array}$} & \multirow{2}{*}{$\mathrm{HI}$} & TDI & EFSA & $\begin{array}{l}\text { Effects on reproduction } \\
\text { and development }\end{array}$ & \multirow{2}{*}{$\begin{array}{l}\text { NOAEL } \\
\text { LOAEL }\end{array}$} \\
\hline & & & & & & & RfD & Denmark EPA & Anti-Androgenic & \\
\hline \multirow{2}{*}{ Jardim et al. (2014) } & \multirow{2}{*}{$\begin{array}{c}\text { OPs (7) } \\
\text { Pyrethroids (4) }\end{array}$} & \multirow{2}{*}{$\begin{array}{c}\text { Dietary } \\
\text { contamination }\end{array}$} & \multirow{2}{*}{ Multiple } & \multirow{2}{*}{ Yes } & \multirow{2}{*}{$\begin{array}{l}\text { Contamination } \\
\text { data }\end{array}$} & \multirow{2}{*}{ RPF } & RPF & $\begin{array}{c}\text { Caldas et al. (2006) } \\
\text { U.S. EPA } \\
\end{array}$ & \multirow{2}{*}{ AChE activity } & \multirow{2}{*}{$\begin{array}{l}\text { NOAEL } \\
\text { BMD }\end{array}$} \\
\hline & & & & & & & RfD & $\begin{array}{c}\text { JMPR } \\
\text { U.S. EPA } \\
\end{array}$ & & \\
\hline \multirow{2}{*}{$\begin{array}{l}\text { Leeman et al. } \\
\quad(2013)\end{array}$} & \multirow{2}{*}{$\begin{array}{c}\text { CBs (7) } \\
\text { OPs (26) } \\
\text { Phthalates (6) }\end{array}$} & \multirow{2}{*}{$\begin{array}{c}\text { Dietary } \\
\text { contamination }\end{array}$} & \multirow{2}{*}{$\begin{array}{l}\text { AChE inhibitors } \\
\text { AChE inhibitors } \\
\text { Anti-androgenic }\end{array}$} & \multirow[b]{2}{*}{ Yes } & \multirow{2}{*}{$\begin{array}{l}\text { Contamination } \\
\text { data }\end{array}$} & \multirow[b]{2}{*}{ RPF } & RPF & Calculated & \multirow[b]{2}{*}{ na } & \multirow[b]{2}{*}{ na } \\
\hline & & & & & & & $\begin{array}{c}\text { ADIRf } \\
\text { D }\end{array}$ & EU Pesticide Database & & \\
\hline Borg et al. (2013) & PFASs (17) & $\begin{array}{c}\text { Dietary } \\
\text { contamination } \\
\text { Urinary } \\
\text { measurement } \\
\end{array}$ & Multiple & Yes & $\begin{array}{l}\text { Biomonitoring } \\
\text { data }\end{array}$ & $\mathrm{HI}$ & RfD & Calculated & $\begin{array}{c}\text { Hepatotoxicity } \\
\text { Reproductive toxicity }\end{array}$ & $\begin{array}{l}\text { NOAEL } \\
\text { LOAEL } \\
\text { BMD }\end{array}$ \\
\hline Beko et al. (2013) & Phthalates (3) & $\begin{array}{c}\text { Residential } \\
\text { (dust } \\
\text { contamination) } \\
\text { Urinary } \\
\text { measurement } \\
\end{array}$ & Anti-androgenic & Yes & $\begin{array}{c}\text { Biomonitoring } \\
\text { data } \\
\text { Contamination } \\
\text { data }\end{array}$ & $\mathrm{HI}$ & TDI & EFSA & $\begin{array}{l}\text { Effects on reproduction } \\
\text { and development }\end{array}$ & $\begin{array}{l}\text { NOAEL } \\
\text { LOAEL }\end{array}$ \\
\hline \multirow{2}{*}{$\begin{array}{l}\text { Kalantari et al. } \\
\quad(2013)\end{array}$} & & Dietary & Reduction of & & Contamination & RPF & RPF & Kalantari et al. (2012) & Hepatic retinoids & na \\
\hline & PCBS (5) & contamination & hepatic retinoid & Yes & data & $\begin{array}{l}\text { Combine } \\
\text { d MOE }\end{array}$ & RfD & Calculated & Body/liver weights & $\mathrm{BMD}_{05}$ \\
\hline $\begin{array}{l}\text { Beamer et al. } \\
\text { (2012) }\end{array}$ & OPs (2) & $\begin{array}{c}\text { Dietary } \\
\text { contamination } \\
\text { Residential } \\
\text { (media } \\
\text { contamination) } \\
\end{array}$ & AChE inhibitors & Yes & $\begin{array}{l}\text { Contamination } \\
\text { data }\end{array}$ & $\begin{array}{c}\text { RPF } \\
\text { HI }\end{array}$ & $\begin{array}{l}\text { RPF } \\
\text { RfD }\end{array}$ & U.S. EPA & $\begin{array}{c}\text { ChE inhibition (plasma, } \\
\text { RBC) } \\
\text { ChE inhibition (brain) }\end{array}$ & $\begin{array}{l}\mathrm{BMD}_{10} \\
\text { NOAEL }\end{array}$ \\
\hline Søeborg et al. & & Urinary & Anti-androgenic & Yes & Biomonitoring & HI & TDI & EFSA & $\begin{array}{c}\text { Effects on reproduction } \\
\text { and development }\end{array}$ & NOAEL \\
\hline (2012) & Pnnnalates (4) & measurement & Anti-anarogenic & res & data & $\mathrm{HI}$ & RfD & $\begin{array}{c}\text { Kortenkamp and Faust } \\
(2010)\end{array}$ & Anti-Androgenic & LOAEL \\
\hline Ragas et al. (2011) & $\begin{array}{c}\text { CBs (1) } \\
\text { Neonicotinoids (1) } \\
\text { OCs (1) } \\
\text { OPs (2) } \\
\text { Pyrethroids (1) } \\
\end{array}$ & $\begin{array}{c}\text { Dietary } \\
\text { contamination }\end{array}$ & $\begin{array}{l}\text { Nervous system } \\
\text { Liver }\end{array}$ & Yes & $\begin{array}{l}\text { Contamination } \\
\text { data }\end{array}$ & $\mathrm{HI}$ & ADI & $\begin{array}{c}\text { EC } \\
\text { WHO }\end{array}$ & na & na \\
\hline Koch et al. (2011) & Phthalates (3) & $\begin{array}{c}\text { Urinary } \\
\text { measurement }\end{array}$ & Anti-androgenic & Yes & $\begin{array}{c}\text { Biomonitoring } \\
\text { data }\end{array}$ & HI & TDI & EFSA & $\begin{array}{c}\text { Effects on reproduction } \\
\text { and development }\end{array}$ & $\begin{array}{l}\text { NOAEL } \\
\text { LOAEL }\end{array}$ \\
\hline $\begin{array}{l}\text { Kortenkamp and } \\
\text { Faust (2010) }\end{array}$ & $\begin{array}{c}\text { OCs (1) } \\
\text { OPs (1) } \\
\text { Parabens (2) } \\
\text { Phenols (1) } \\
\end{array}$ & - & Anti-androgenic & No & $\begin{array}{l}\text { Contamination } \\
\text { data }\end{array}$ & $\mathrm{HI}$ & RfD & Calculated & Anti-androgenic & $\begin{array}{l}\text { NOAEL } \\
\text { LOAEL } \\
\text { BMDL }\end{array}$ \\
\hline
\end{tabular}




\begin{tabular}{|c|c|c|c|c|c|c|c|c|c|c|}
\hline & $\begin{array}{c}\text { Phthalates (5) } \\
\text { PBDEs (1) } \\
\text { Other classes of } \\
\text { pesticides (4) }\end{array}$ & & & & & & ADI & EFSA & & \\
\hline Linares et al. (2010) & PAHs (3) & $\begin{array}{c}\text { Chemical and } \\
\text { petrochemical } \\
\text { industries } \\
\text { emissions }\end{array}$ & - & Yes & $\begin{array}{c}\text { Contamination } \\
\text { data }\end{array}$ & HI & RfD & U.S. EPA & na & na \\
\hline Bosgra et al. (2009) & OPs (31) & $\begin{array}{c}\text { Dietary } \\
\text { contamination }\end{array}$ & AChE inhibitors & Yes & $\begin{array}{c}\text { Contamination } \\
\text { data }\end{array}$ & $\begin{array}{c}\text { RPF } \\
\text { Combine } \\
\text { d MOE }\end{array}$ & RPF & Calculated & AChE activity & $\mathrm{BMD}_{20}$ \\
\hline Benson (2009) & Phthalates (5) & - & Anti-androgenic & Yes & $\begin{array}{l}\text { Biomonitoring } \\
\text { data }\end{array}$ & $\begin{array}{c}\text { RPF } \\
\text { HI }\end{array}$ & RfD & Calculated & Anti-Androgenic & $\begin{array}{l}\text { NOAEL } \\
\text { LOAEL } \\
\text { BMDL }\end{array}$ \\
\hline \multirow[b]{2}{*}{ Boon et al. (2008) } & \multirow{2}{*}{$\begin{array}{l}\text { OPs (26) } \\
\text { CBs (8) }\end{array}$} & \multirow{2}{*}{$\begin{array}{c}\text { Dietary } \\
\text { contamination }\end{array}$} & \multirow[b]{2}{*}{$\mathrm{AChE}$ inhibitors } & \multirow[b]{2}{*}{ Yes } & \multirow{2}{*}{$\begin{array}{l}\text { Contamination } \\
\text { data }\end{array}$} & \multirow[b]{2}{*}{ RPF } & RPF & Calculated & \multirow[b]{2}{*}{ AChE activity } & \multirow{2}{*}{$\begin{array}{l}\text { NOAEL } \\
\mathrm{BMD}_{10}\end{array}$} \\
\hline & & & & & & & RfD & JMPR & & \\
\hline $\begin{array}{c}\text { Durmusoglu et al. } \\
(2007)\end{array}$ & $\begin{array}{l}\text { Phenols (1) } \\
\text { PAHs (4) }\end{array}$ & $\begin{array}{c}\text { Tire industries } \\
\text { emissions }\end{array}$ & $\begin{array}{c}\text { Respiratory } \\
\text { irritation }\end{array}$ & No & $\begin{array}{c}\text { Contamination } \\
\text { data }\end{array}$ & $\mathrm{HI}$ & RfD & U.S. EPA & Not specific & na \\
\hline \multirow{2}{*}{ Caldas et al. (2006) } & \multirow{2}{*}{$\begin{array}{l}\text { OPs (22) } \\
\text { CBs (3) }\end{array}$} & \multirow{2}{*}{$\begin{array}{c}\text { Dietary } \\
\text { contamination }\end{array}$} & \multirow{2}{*}{ AChE inhibitors } & \multirow{2}{*}{ No } & \multirow{2}{*}{$\begin{array}{l}\text { Contamination } \\
\text { data }\end{array}$} & \multirow{2}{*}{ RPF } & RPF & Calculated & \multirow{2}{*}{ AChE activity } & \multirow{2}{*}{$\begin{array}{l}\text { NOAEL } \\
\text { BMD }_{10}\end{array}$} \\
\hline & & & & & & & RfD & JMPR & & \\
\hline $\begin{array}{c}\text { Castorina et al. } \\
\text { (2003) }\end{array}$ & OPs (11) & $\begin{array}{l}\text { OPs commonly } \\
\text { applied } \\
\text { that metabolize } \\
\text { dialkyl } \\
\text { compounds }\end{array}$ & AChE inhibitors & Yes & $\begin{array}{c}\text { Biomonitoring } \\
\text { data }\end{array}$ & $\begin{array}{c}\text { RPF } \\
\text { Combine } \\
\text { d MOE }\end{array}$ & RPF & Calculated & AChE activity & $\mathrm{BMD}_{10}$ \\
\hline
\end{tabular}

$\mathrm{AChE}=$ acetylcholinesterase $; \mathrm{ADI}=$ Acceptable daily intake $\mathrm{CBs}=$ Carbamates DNEL $=$ Derived no effect level $; \mathrm{EC}=$ European Commission; $\mathrm{HI}=\mathrm{Hazard}$ index $; \mathrm{HQ}=\mathrm{Hazard}$ quotient; JMPR = Joint FAO/WHO Meeting on Pesticide Residues; MOE = margin of exposure; na = not available; OCs = Organochlorines; OPs = Organophosphorus; PAHs = Polycyclic aromatic hydrocarbons; PCBs = Polychlorinated biphenyls; PFAs = Perfluoroalkoxy alkanes; POD = Point of departure; POPs = Persistent organic pollutants; RBC = Red blood cell; RfD = Reference dose. 